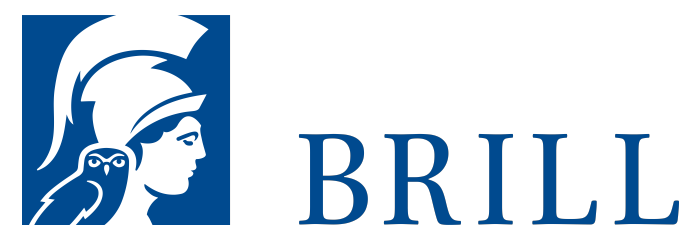

\title{
Absichtliches Handeln
}

\section{Author: David Horst}

Eine absichtliche Handlung ist eine Bewegung, in deren Vollzug das Subjekt der Bewegung durch sein Denken geleitet ist. Der Begriff des absichtlichen Handelns bezeichnet mithin eine bestimmte Einheit von Denken und Bewegung. Diese Einheit zu verstehen ist die Aufgabe der philosophischen Handlungstheorie. Im vorliegenden Buch entwickele ich ein neuartiges VerstÃ̋ndnis dieser Einheit und damit des Begriffs des absichtlichen Handelns. Wer etwas absichtlich tut, so die These, weiÃŸ, was er tut. Dieses Wissen, das der Handelnde von dem hat, was er tut, ist dabei von ganz besonderer Art: es ist ein praktisches Wissen. Praktisches Wissen, so sage ich im Anschluss an G.E.M. Anscombe, ist ein Wissen, das die Ursache dessen ist, was es versteht. Um also zu verstehen, was es heiÃŸt, absichtlich zu handeln, muss man verstehen, was praktisches Wissen ist.

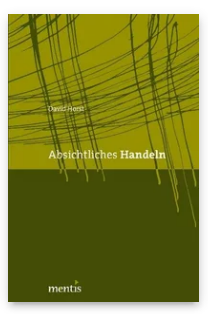

Pages: 205

Seiten

Language:

German

Subjects:

General,

Philosophy

Publisher: Brill | mentis

E-Book (PDF)

Released online:

o1 Jan 2012

ISBN: $978-3^{-}$

95743-965-9

List price

USD Â $\$ 52.00$

Paperback

Publication date:

O1 Jan 2012

ISBN: $978-3^{-}$

89785-76o-5

List price

USD Â $\$ 52.00$ 
For more information see brill.com

Order information: Order online at brill.com +44330 333 0049 | customerservices@brill.com Submission information: brill.com/authors

Titles published by Brill | Fink, Brill | mentis or Brill | Schöningh: +49(o)715413279216| brill@brocom.de 